\title{
Element szczególny w otoczeniu - ślady Rotunda romańska na Wzgórzu Tumskim w Płocku
}

\section{Sławomir Paweł Markowski}

\section{STRESZCZENIE}

Od zarania cywilizacji człowiek - homo constructor - intuicyjnie dąży do przekształcania swego otoczenia oraz porządkowania go według sobie znanego sensu, w sposób bardziej lub miej trwały. W tej działalności nie tylko wielkie budowle, ale nawet te najmniej trwałe człowiecze dzieła, stają się w pewnej przestrzeni czasowej śladem - sygnum twórczych działań.

Artykuł zawiera rys historyczny romańskiej rotundy - szczególnego elementu w przestrzeni krajobrazu kulturowego Wzgórza Tumskiego w Płocku, która pozostaje nie tylko jako ślad w płaszczyźnie programowej tego miejsca, ale dziś jest rzeczywistym śladem - symbolicznie zaznaczonym miejscem jej istnienia.

Jest to jeden z tych śladów, który raz, że spełnia oczywistość historyczną a dwa - staje się ekspozycją elementu szczególnego w krajobrazie.

Słowa kluczowe: element szczególny, ślad, rotunda

\section{Wprowadzenie}

Unikatowy charakter wznoszącego się pięćdziesiąt metrów nad lustrem wód Wisły Wzgórza Tumskiego w Płocku, wynika z pozornie banalnego, nieomal gestaltycznego widzenia jego przestrzeni, w której trwają dzieła architektury i przyrody. Przez setki lat funkcjonowali tu ludzie tworzący specyficzną przestrzeń o ściśle określonym programie, składającą się z zespołu miejsc szczególnych - sacrum i profanum.

Jest to zespół zabytków o ponadregionalnej wartości, zasługujący na szczególne zachowanie w pamięci ich funkcji. Dominują gmachy - katedry opactwa pobenedyktyńskiego i wież zamkowych - świadkowie wielkiej i burzliwej historii tego miejsca. Katedra biskupia pw. Wniebowzięcia N.M.P., zbudowana przez biskupa Aleksandra z Malonne [Grabowski 1970, s. 15] na gruzach świątyni Chrobrego, istnieje tu od 1144 roku$^{1}$. Po licznych przebudowach ceglano-kamienny gmach zawiera dziś w sobie style: romański, gotycki i renesansowy - kulturową zmienność w biegu czasów. Sytuowane obok budynki opactwa swym początkiem wiążą się z rokiem 1065, gdy założono opactwo benedyktynów w Mogile. Ich czworobok uzupełnia wieża, zwana Zegarową i baszta zamkowa zwana Szlachecką.

W treści artykułu zachowano wierność jego tytułowi, uważając ślad po rotundzie romańskiej, jako element szczególny w krajobrazie Wzgórza Tumskiego, który w początkach lat XXI w. zaznaczono wybudowaniem dwóch murków kamiennych, ustawionych w półokręgi.

\footnotetext{
${ }^{1}$ O konsekracji tej świątyni pisał dr W. Wszerecz kan. pł. Spominki płockie i spominki sochaczewskie, Monumenta Poloniae Historica, Lwów 1878, t. III, s. 119.
} 


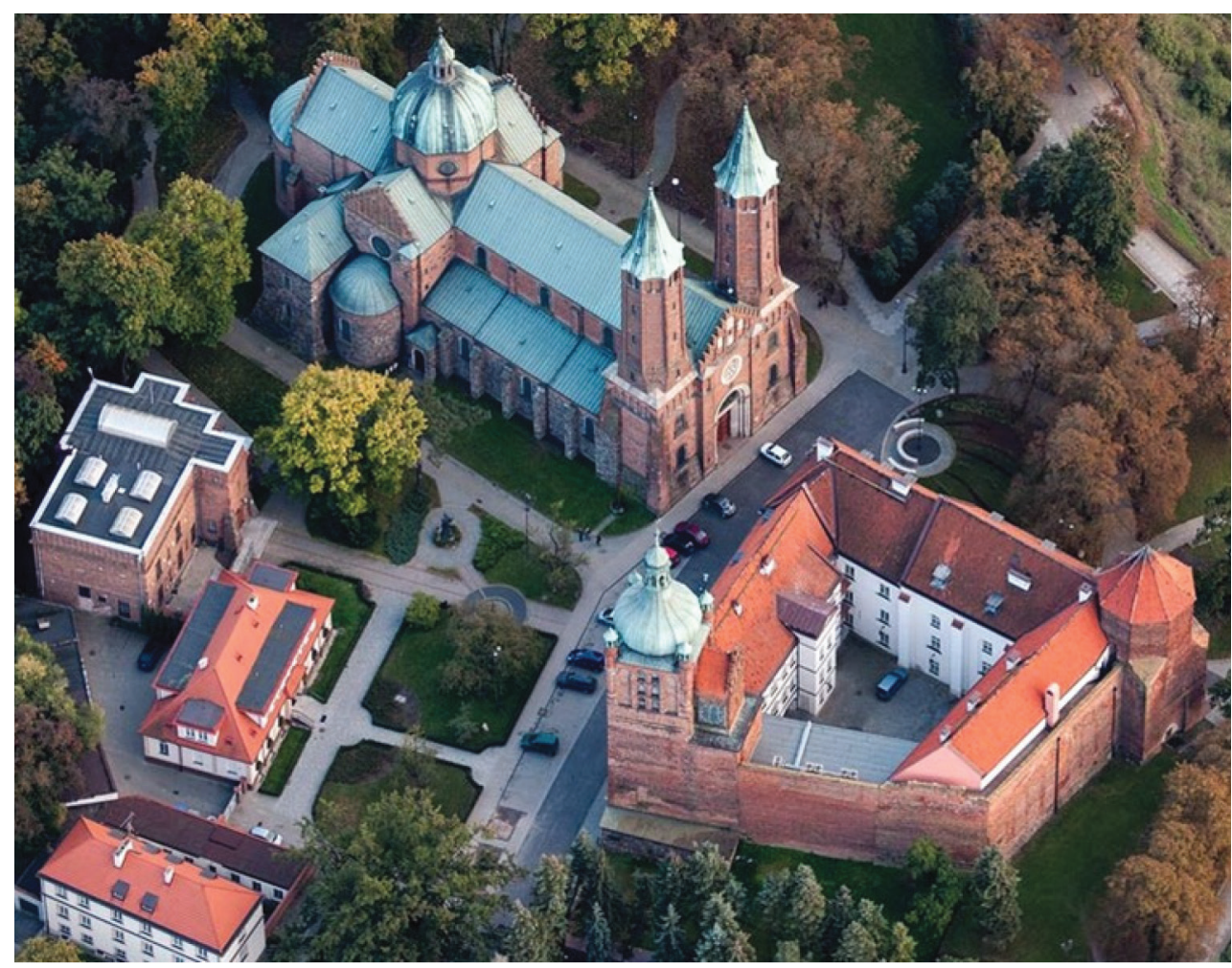

Ryc. 1. Wzgórze Tumskie w Płocku. W górnej części fotografii katedra w kształcie po przebudowie z lat 1900-1903. Przed frontonem katedry widoczny okrąg kamiennych murków zaznaczający istnienie w tym miejscu rotundy romańskiej

\section{Źródło: www.zamki.pl}

Podbudowę artykułu, o dość hipotetycznym wybrzmieniu, stanowi analiza związków historyczno-architektonicznych związanych z zabudową Wzgórza Tumskiego oraz oparcie się na wynikach dotychczasowych ustaleń badaczy na temat zachowania i interpretacji zespołu reliktów rotundy. Nadal nieznane są najstarsze koleje zabudowy przestrzeni Wzgórza, w tym niedoprecyzowanie ewentualnych faz powstawania budowli sakralnych, jak i świeckich w ich wzajemnych relacjach funkcjonalnych. Dlatego stan ten pozwala na dość szeroką interpretację funkcji obiektu oraz postawienie nawet kontrowersyjnych hipotez.

Artykuł nie ma charakteru krytycznych rozważań nad dokonaniami naukowymi badaczy przedmiotu i nie uzurpuje sobie prawa do przedstawiania w tym zakresie jedynej racji. Jest jedynie zapisem referatu wygłoszonego na IV Międzynarodowej Konferencji ArtystycznoNaukowej KRAJart 2017, na temat „Element szczególny w otoczeniu - ślady”, organizowanej przez Wyższą Szkołę Ekologii i Zarządzania w Warszawie. 


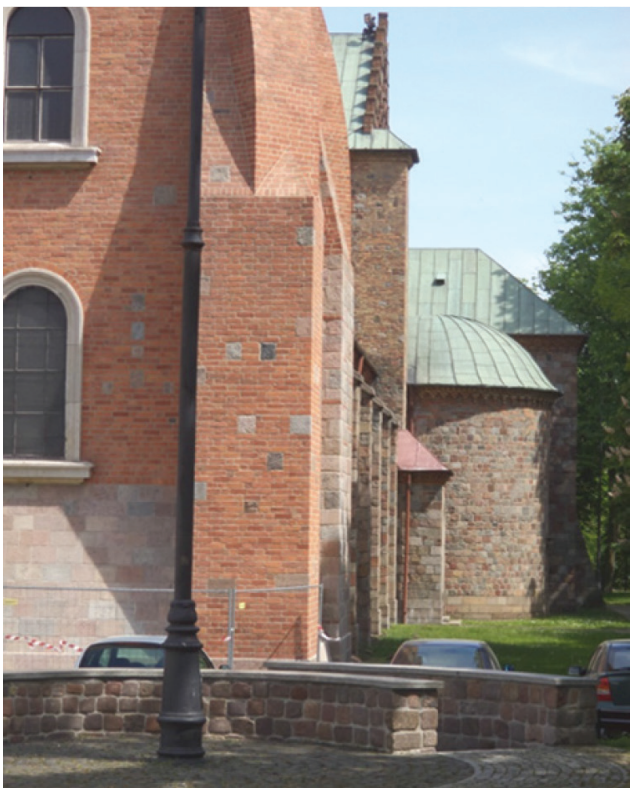

Ryc. 2. Murki, jako miejsce po rotundzie Fot. S.P. Markowski, 2017

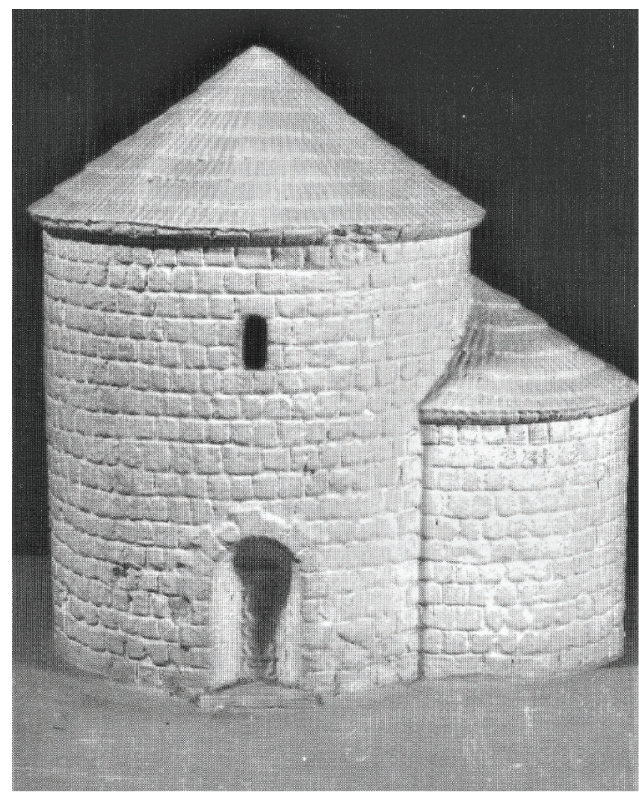

Ryc. 3. Rekonstrukcja rotundy Źródło: T. Kordala, Płock w zaraniu dziejów

\section{Analiza danych problemowych}

Treść rozważań niniejszego studium ma początek łączący się z rokiem 1959, kiedy to $\mathrm{w}$ trakcie prowadzonych systemowo na Wzgórzu Tumskim prac wykopaliskowych, prof. Włodzimierz Szafrański ${ }^{2}$ odsłonił przed zachodnią fasadą katedry, nieco na południe w rejonie parku kasztanowców, nikłe relikty wczesnośredniowiecznego założenia architektonicznego [Szafrański 1963]. Były to fragmenty fundamentów „rotundy grodowej”, budowli o szczególnym charakterze i znaczeniu w architekturze i historii grodu płockiego.

Odkrycie zinterpretowano "rotundą na podgrodziu” bądź "rotundą grodową" [Sokołowski 1975, s. 16] dokonując rekonstrukcji budowli, jako wolnostojącej rotundy z głęboką apsydą od wschodu [Szafrański 1963, s. 2-3; 1966a, s. 230; 1983, s. 53-57]. Nikłe relikty założenia pozyskiwane $\mathrm{w}$ trakcie kilku sezonów prac badawczych prowadziły do tworzenia dziś kolejnych, dość rozbieżnych interpretacji funkcji odkrytego obiektu i jego miejsca w chronologii, co utrudnia jego jednoznaczne włączenie do rekonstrukcji historycznych. Nie jest to przypadek odosobniony, gdyż „Dotychczasowe ustalenia dotyczące chronologii - wbrew zbyt optymistycznym wnioskom wielu archeologów, ochoczo podchwytywanym przez historyków, nie mają w rzeczywistości uzasadnienia ani źródłowego, ani nie mają zastosowania w bardziej precyzyjnych metodach datowania" [Sikorski 2012, s. 9].

\footnotetext{
${ }^{2}$ Prof. Włodzimierz Szafrański (1920-1998) - polski historyk, archeolog, religioznawca, „odkrywca średniowiecznego Płocka”.
} 


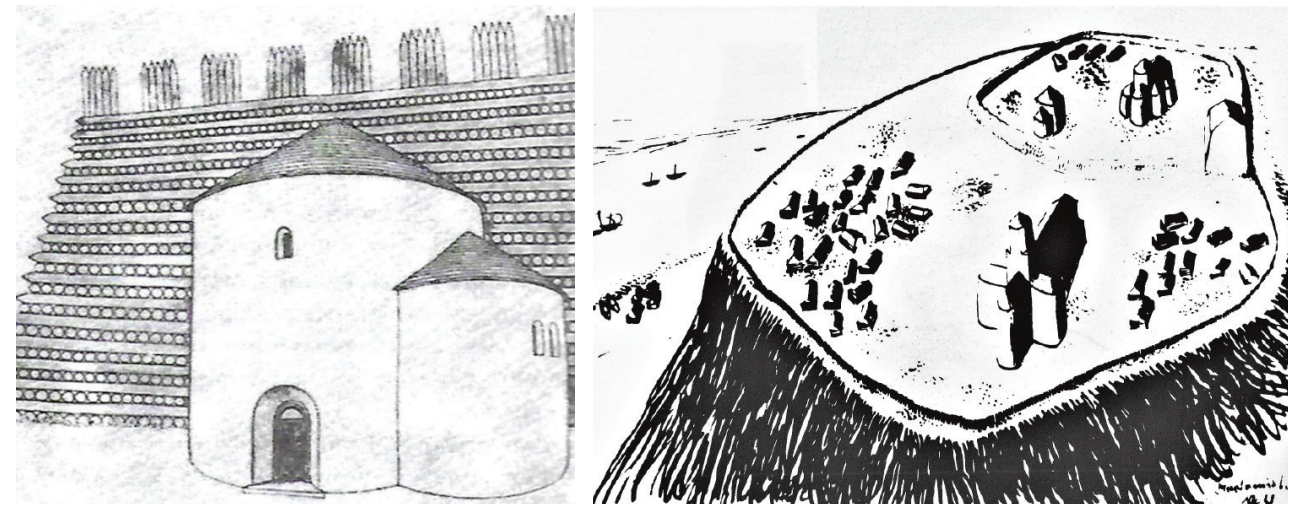

Ryc. 4. i 5. Rekonstrukcja rysunkowa rotundy na Wzgórzu Tumskim wg W. Szafrańskiego Źródło: Sprawozdanie archeologiczne badań wykopaliskowych w 1961 r. W. Szafrański

Dla zagadnienia podjętego $\mathrm{w}$ temacie niniejszego artykułu, istotnym jest fakt dopatrywania się przez badacza odkrytej rotundy, (nieopodal podpory empory) w jednej ze "struktur wgłębnych" struktury fundamentowej, formy zinterpretowanej jako grobowiec książęcy [Szafrański 1983, s. 57-62, 89]. Poprowadzenie rozpoznawania tego elementu w kontekście zdarzeń historycznych w adekwatnym czasie, pozwoliło na widzenie rotundy jako miejsca o szczególnej funkcji liturgicznej - baptysterium, a nie sepulkralnej - jako miejsca pochówku władcy. Chociaż możliwym jest, że funkcja tego miejsca mogła zmieniać się w czasie i następować jedna po drugiej. Tu zdania archeologów nie są zgodne, gdyż nie posiadają punktu zaczepienia dotyczącego precyzyjnego datowania.
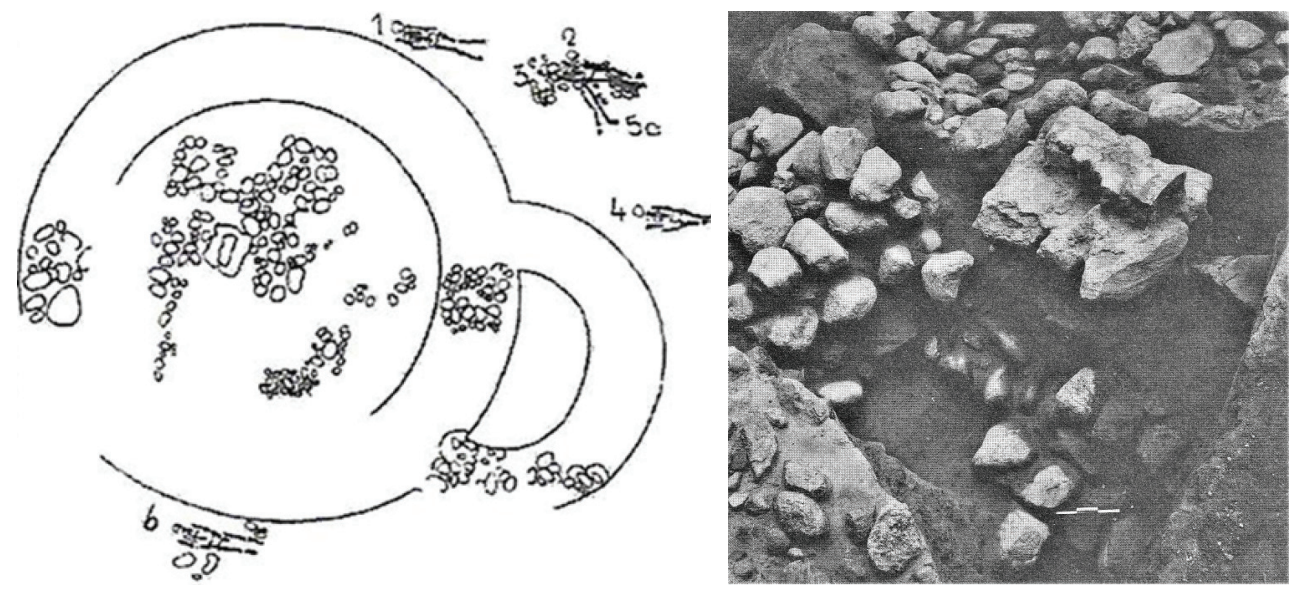

Ryc. 6. i 7. Rysunek i fotografia struktur fundamentowych z widocznymi reliktami podstawy empory

i tzw. „struktury wgłębnej” - interpretowanej jako ślad po basenie chrzcielnym (przyp. aut.)

Źródło: Sprawozdanie archeologiczne badań wykopaliskowych w 1961 r. W. Szafrański 
Dlatego wobec nikłego stopnia rozpoznania budowli uwzględnianego w literaturze przedmiotu [Tomaszewski 1974; Rodzińska-Chorąży 1995; Pianowski 1994] powstała możliwość (na potrzeby spełnienia tytułu niniejszego artykułu) postawienia ostrożnego, hipotetycznego stwierdzenia przy interpretowaniu owej „struktury wgłębnej”, o istnieniu w tym miejscu śladu po użytkowaniu basenu chrzcielnego (przyp. autora), a to wprost wiązałoby się z funkcją baptysterialną rotundy.

W świetle ostatnich badań archeologicznych [Gołembnik 2002], funkcja ta zdaje się nie była określoną w momencie powstawania obiektu, chociaż nie można tego negować do końca. Na podstawie analizy dokumentacyjnej A. Gołembnik przypuszcza, że odsłonięte w tych badaniach struktury fundamentu kamiennego są pozostałością zaświadczającą nie tylko o dwufazowym powstawaniu rotundy, a również o możliwym istnieniu innych struktur z czasów przed powstaniem pierwszego założenia rotundy. To natomiast pozostaje w sprzeczności z przyjętą przez Szafrańskiego tezą o jednofazowym założeniu, a za tym idącym jednoznacznym przeznaczeniu. Początkowo datował on budowę świątyni na lata 30. XI w., a więc czas panowania w Płocku Miecława, by wkrótce uściślić tę datę na przełom lat 1008/1009, co z kolei oparte było na wydedukowanej dacie pobytu w Płocku św. Brunona z Querfurtu³ [Szafrański 1983, s. 80], stąd również określenie „rotunda Brunona” [Bukowska 2011, s. 190]. Bowiem jak zostało przyjęte w materiałach historiograficznych, biskup Brunon - przyjaciel $^{4}$ Bolesława Chrobrego - z Płocka wyruszył na misję nawracania pogańskich Prusów i Jaćwingów, a to wiązało się z nagłym wykonaniem odpowiedniej oprawy architektonicznej dla siedziby misyjnej. W zasadzie upewnieniu tegoż datowania nie zaprzeczają np. badania M. Trzecieckiego [Gołembnik 2011], dotyczące całej akcji budowlanej na Wzgórzu Tumskim, pomimo iż finalnie odnosi jej czas dopiero na schyłek XI w., zaś znamiennym jest przesuwanie wstecz datowania owych inwestycji budowlanych w Płocku, które nie zostało zakończone wraz z ostatnimi badaniami archeologicznymi. Toteż np. „... hipoteza o istnieniu założenia wcześniejszego niż rotunda wymaga weryfikacji terenowej w przyszłości" [Bukowska 2011, s. 201].

Zatem, ogólnie zakres czasowy powstawania świątyni można ująć w dwóch fazach. Pierwsza odnosi się do czasu jej budowy, prawdopodobnie jako kościoła misyjnego ${ }^{5}$, mającego ścisły związek z działalnością w Płocku, św. Brunona z Querfurtu. Druga faza odnosi się do odbudowy po zniszczeniach spowodowanych najazdem Jarosława Mądrego w 1031 r., lub też tzw. reakcji pogańskiej ${ }^{6}$, kiedy to prawdopodobnie wraz z innymi

\footnotetext{
Bruno Bonifacy z Kwerfurtu (Querfurtu) (974-1009) mnich benedyktyński, kapelan cesarski, biskup misyjny, współtwórca chrystianizacji Polan i apostoł Pomorza, męczennik - święty Kościoła katolickiego.

4 O zażyłej przyjaźni świadczy fragment listu Brunona skierowanego do Henryka II z 1008 roku: „jeśliby doleciała do Ciebie wieść, że królowi polskiemu za wiele przywiązania i za wiele wierności okazuję, tedy wiedz, że istotnie kocham go jak mojąduszę, a więcejniżmojeżycie" (zaW.Szafrańskim DziejePłocka,s.50)również:BrunozKwerfurtu:ListdokrólaHenrykaII [w:] Piśmiennictwo czasów Bolesława Chrobrego, Kazimierz Abgarowicz (tłum.) PWN, Warszawa 1966, s. $247-261$.

5 "Wiemy bowiem z relacji Wiparta, że Bruno z Kwerfurtu wyprawił się do Jaćwieży opuszczając własną diecezję, którą rządził w Polsce" (W. Szafrański, Dzieje Płocka, s. 38 za J. Bieniakiem).

${ }^{6}$ Literatura przedmiotu podaje różne powody ówczesnych buntów ludności zwanych „reakcją pogańską". Za dość ważne badacze uznają zmiany, do których zmuszano ludność w związku z chrystianizacją: przyjęcie nowych norm obyczajowych i zasad religijnych. Na pierwszym miejscu (m.in. G. Labuda) jednak eksponowane jest obciążenie finansowe wprowadzone-
} 
budowlami na wzgórzu nie oparła się niszczącym zapędom zrewoltowanej społeczności państwa piastowskiego. Toteż nie jest pozbawione racji przypuszczenie, że wówczas rotunda mogła być odbudowana, naprawiana lub po prostu zaadaptowana przez Miecława ok. 1037 r. jako baptysterium7, co nie może się spotkać z jednoznaczną negacja, gdyż wiązało się z programem politycznym tego, ówczesnego władcy Mazowsza ${ }^{8}$. W tym kształcie przetrwała ona do XIII w. ${ }^{9}$, pozostawiając po sobie nikłe elementy $\mathrm{w}$ warstwie fundamentowej, odkryte w XX w.

$\mathrm{W}$ literaturze przedmiotu temat kościołów romańskich, z przypisaniem im charakteru ściśle baptysterialnego, na terenach polskich jest nieomal całkowicie odosobniony. Toteż istnienie rotundy na Wzgórzu Tumskim w Płocku badacze chętniej odnoszą do tzw. kościoła Dobiechny [Zachwatowicz 1971], a więc „kościoła grodowego”10 o zwykłej funkcji liturgicznej. Wiąże się to w czasie z prawdopodobną odbudową rotundy w latach 1130-1150 przez Dobiechnę, wdowę po Wojsławie, piastunie Bolesława Krzywoustego. Ma to związek z opinią przyjętą przez mediewistów, według której świątynia ta miała być zniszczona przez najazd Pomorzan w latach 20. XII w., co kronikarz Ebbon w dziele Vita Ottonis ${ }^{11}$ zaznaczył pisząc „... agresja najeźdźców wyniszczyła ludność grodu, a dzikość okazali wyciągając z grobów zwłoki jego rodziców (Władysława Hermana i Judyty), powybijawszy zęby, i rozpraszając kości".

Podobnie w kontekście baptysterialnym, prof. Teresa Mroczko [1978], odnosząc się do tematu dzieł romańskich w Polsce w swej pracy przypuszcza, że w Polsce baptysteria jako osobne budynki nie były nigdy budowane. Zatem trwając w podobnej wykładni niektórych badaczy, rotunda płocka byłaby tylko osobną świątynią istniejącą jedynie na potrzeby biskupa, co i owszem zgadza się z ówczesnym ogólnym programem chrystianizacyjnym, dla którego przyjęto, że rotundy jednoapsydowe mogły istnieć wówczas również jako kościoły o charakterze misyjnym.

przez instytucje władzy państwowej oraz kościoła - dziesięcina i świętopietrze. Nazwanie przez ówczesnych kronikarzy (patrz: Gall Anonim) zbuntowanej ludności poganami, wynikało z faktu zdyskredytowania ich w oczach chrześcijańskiej opinii publicznej.

7 Baptysterium, był to budynek przeznaczony wyłącznie do obrzędu chrztu, zwany też kościołem chrzcielnym. Głównym elementem budynku była piscina, zbiornik na wodę. Wznoszony był jako budowla wolnostojąca, na ogół w pobliżu większego kościoła, przeważnie katedralnego, po jego zachodniej stronie. Taka też jest topografia na Wzgórzu Tumskim, przy katedrze Ottonowskiej.

8 „W kronice ruskiej Powieść lat minionych oraz w polskiej Galla Anonima (obie z początków XII w.) jest mowa o Mazowszu w kontekście walk związanych z kryzysem piastowskiej monarchii w latach 30. XI w. oraz ze stłumieniem przez Polskę i Ruś samodzielnych rządów Miecława" [Kordala 1995].

${ }^{9}$ W 1262 r. nastąpił jeden z największych najazdów łupieżczych na Płock. Litwini prowadzeni przez ks. Mendoga i nowogrodzianie pod wodzą ks. Izjasława, spalili i złupili katedrę, rotundę i zamek. Wówczas prawdopodobnie zrabowane zostały również brązowe Drzwi Płockie.

10 Terminowi „kościół grodowy” niektórzy badacze - także dla X i XI wieku - przypisują bardziej ścisłe znaczenie, widząc w nim coś w rodzaju kościoła parafialnego (protoparafialnego), którego uprawnienia mają się pokrywać z okręgiem grodowym [Sikorski 2012, s. 19].

11 Żywotopisarz Ebbon był mnichem w klasztorze św. Michała koło Bambergu. W dziele Vita Ottonis Episcopi Babenbergensis $w$ XII $w$. opisał żywot św. Ottona z Bambergu, kanclerza cesarza Henryka IV, misjonarza, świętego Kościoła katolickiego, zwanego „Apostołem Pomorza”. 
Jednakże w świetle zdarzeń historycznych mających miejsce na Mazowszu, szczególnie w XI w., warto bronić charakteru rotundy tumskiej właśnie jako Miecławowego baptysterium. I to jest clou wynikające $\mathrm{z}$ tematu artykułu, odnoszące się do szczególnego charakteru tumskiego zabytku. Miecław bowiem, bardziej niż Piastowie, w nowej rzeczywistości politycznej znacząco potrzebował uwiarygodnienia swej władzy nad Mazowszem, jako władcy szerzącego wiarę chrześcijańską. Ponadto oznaczało to otwarcie na chrześcijaństwo innych terenów dotychczas bezpośrednio lub luźno związanych z władztwem piastowskim.

Pomimo, że ciągle pozostają nierozpoznane ówczesne wzajemne relacje funkcjonalnoinstytucjonalne pomiędzy obiektami na Wzgórzu Tumskim, to nasuwa się tu podobieństwo sytuacyjno-czasowe $\mathrm{z}$ baptysterium $\mathrm{w}$ kształcie rotundy $\mathrm{w}$ Eger (Węgry) istniejącej przy katedrze biskupiej, gdzie biskupstwo założył sam św. Stefan. W tej mierze najważniejszym argumentem jest, iż dla Miecława baptysterium stawało się jednym $\mathrm{z}$ narzędzi do prowadzenia polityki. Idąc tym tokiem analizowania, $\mathrm{z}$ takiego podobieństwa znane jest z nieco wcześniejszego okresu baptysterium w kształcie rotundy na Ostrowie Tumskim i Ostrowie Lednickim [Górecki 1998, s. 37].

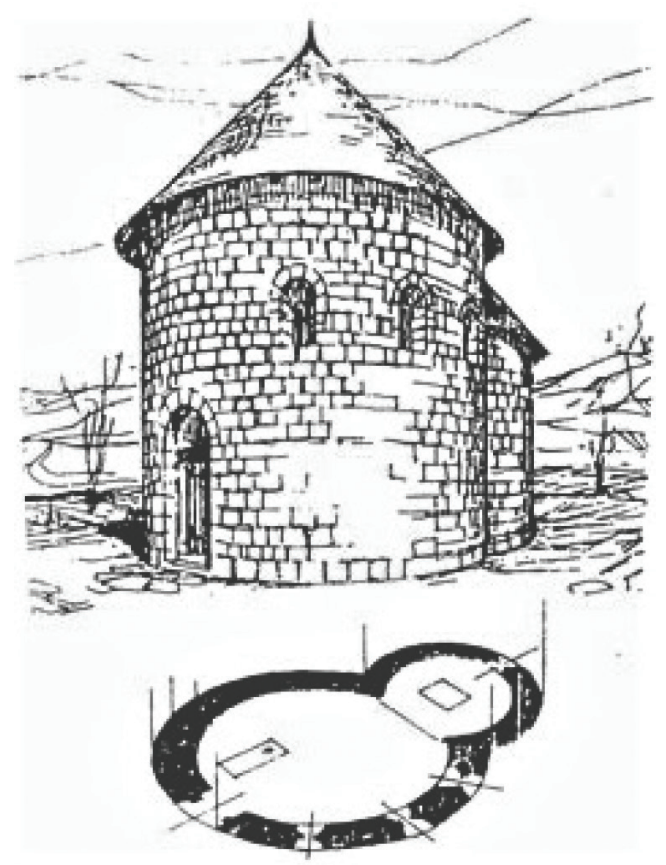

Ryc. 8. Baptysterium w Eger (Węgry) Źródło: https//albumromanski.pl/album/eger

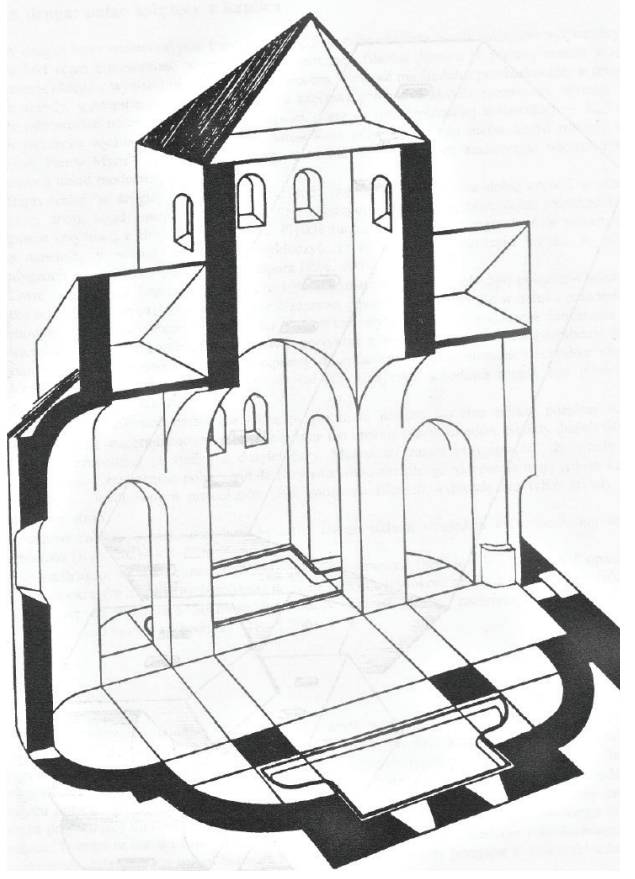

Ryc. 9. Baptysterium lednickie Źródło: ilustr. „Ostrów lednicki” t. I 


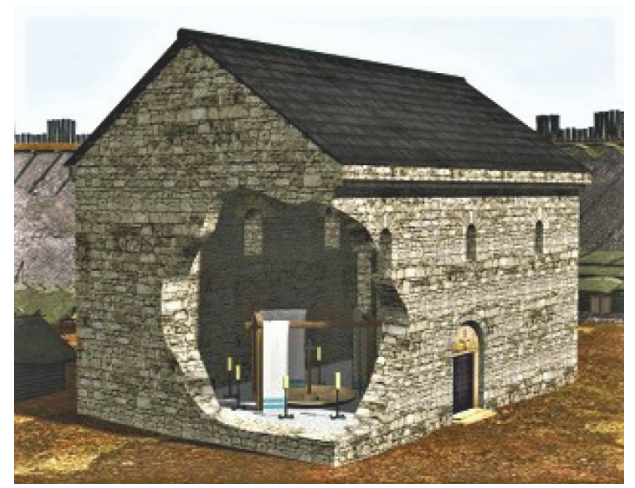

Ryc. 10. Wizualizacja baptysterium Mieszka I Źródło: Poznan.pl wg P. Walichnowskiego

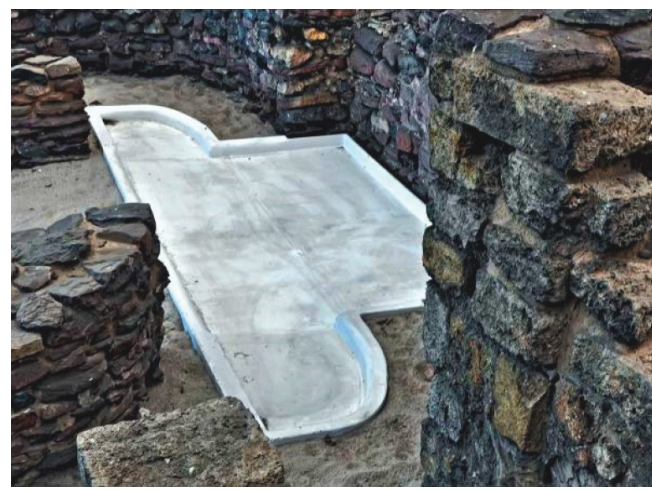

Ryc. 11. Lednica - basen chrzcielny rekonstrukcja Źródło: https://www.google.pl

\section{Rezultat analiz}

Dla podjęcia ważkiej roli w niesieniu wiary chrześcijańskiej na Mazowszu i terenach ościennych, wybudowano misyjnemu biskupowi niewielka, kamienną rotundę. Wielkość świątyni misyjnej w Płocku nie wiązała się bynajmniej z brakiem środków inwestora i skalą szeregu przedsięwzięć budowlanych na Wzgórzu Tumskim w Płocku. Tu interesującym jest fakt samego powstania takiego obiektu. Budowy, w tym miejscu, murowanej świątyni misyjnej z funkcją baptysterialną wymagała sytuacja społeczno-polityczna. Było to wyznacznikiem prestiżu władzy również poprzez to, że w tym czasie i w tym miejscu był to obiekt nowatorski technologicznie i odmienny od budowanych w tradycyjnej umiejętności obróbki drewna zabudowań dworskich i obwarowań grodu. Ugruntowuje to jego znaczenie, tym bardziej gdyż „Spośród zaledwie paruset budowli murowanych jakie powstały (na ziemiach polskich) pomiędzy końcem X, a połową XIII wieku z których zachowało się 162, większość powstała po roku 1200” przy tym pamiętać należy, że „Budownictwo kamienne w warunkach wczesnego państwa polskiego, a także później - to wielki luksus, konieczność sprowadzenia i opłacenia zespołu budowniczych z Zachodu" [Świechowski 2000, s. 15], co charakteryzowało potencjał państwa piastowskiego. Ale był to ciągle czas silnej władzy centralnej Piastów, może zbyt silnej, czemu przeciwstawiły się i wykazały wydarzenia z kolejnych lat buntu w 1022, 1025, 1031, oraz szczególnie w 1034 r.

Dlatego właśnie, w niniejszym artykule, nie przypadkowo podniesiona została kwestia spożytkowania owej świątyni przez Miecława jako baptysterium - naówczas elementu szczególnego w otoczeniu obiektów architektonicznych Wzgórza Tumskiego - signum zamierzchłej gry politycznej, wynika to bowiem z konieczności przywrócenia jej roli, jaką odegrała w historii Płocka.

Przypadek Miecławowy tworzy fakt, w którym rotunda wpisuje się w krąg tych zabytków najstarszej architektury kamiennej w Polsce, jakie funkcjonują jedynie w formach nadanych im na podstawie ciągle wieloznacznych i niejasnych przesłanek źródłowych. 


\section{Podsumowanie}

Na podstawie kwerendy bibliotecznej oraz czynności terenowych pozwalających poznać znaczenie rotundy, przybliżone zostały jedynie fragmentarycznie wydarzenia badawcze mające z nią związek. Stan rozpoznania obiektu pozostaje niezadowalającym nie tylko z pozycji badań historyka. Proces poznawczy przestał postępować, powodując zniekształcenia w obrazie obiektu coraz trudniejsze do skorygowania. W tym zakresie funkcja, jak i relacje rotundy do innych obiektów na Wzgórzu Tumskim w Płocku, sprowadzone zostały do formy symbolicznej - zaznaczenia śladu.

W pewien czas po zakończeniu prac wykopaliskowych, które „przywróciły ją do życia” powstał projekt wyeksponowania w plenerze reliktów rotundy, co skończyło się tym, że miejsce, w którym stała świątynia, zaznaczono na trawniku adekwatnym rysunkiem fundamentów obsadzonym kwiatami. Po ostatnich pracach badawczych, zatem po przeszło półwieczu, pobudowano na pamiątkę kamienny krąg, „pseudorotundę” przybliżający cokolwiek kształtem i materiałem granitowych ciosów rotundę romańską. Powstała kompozycja, będąca niejako parafrazą architektoniczną tego jaką była niegdyś rotunda w swej szczególnej funkcji, tak trudnej dziś do wyartykułowania - ślad po władcach, budowniczych, wyznawcach i barbarzyńcach.
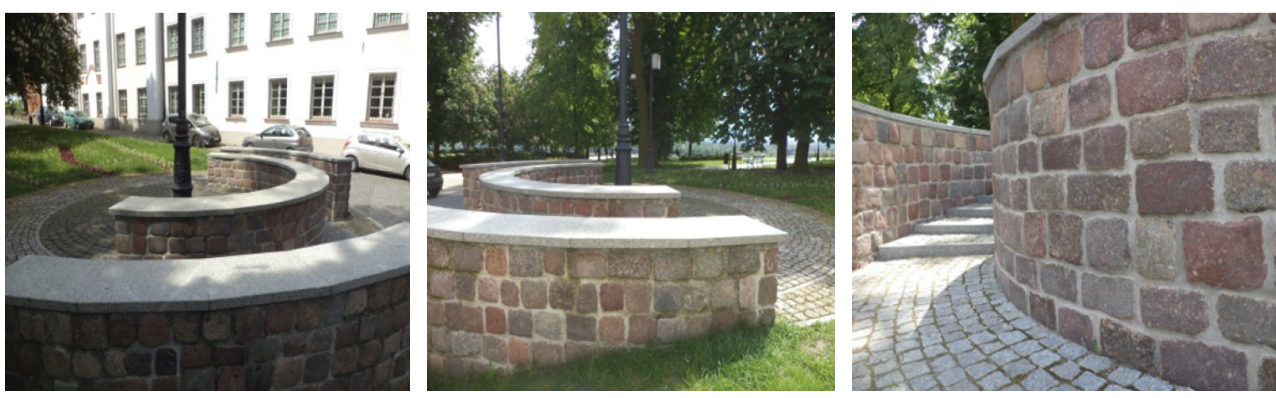

Ryc. 12., 13., 14. „Pseudorotunda”, kręgi murków z ciosów kamiennych jako ślad po rotundzie Fot. S.P. Markowski, 2017

\section{Literatura}

Bieniak J., 2012, Państwo Miectawa. Studium analityczne, Wyd. Naukowe PWN, Warszawa.

Bukowska A., 2011, Relikty architektury wczesnośredniowiecznej - formy i datowanie. Rozdz. V. Płock wczesnośredniowieczny, Trio, Warszawa.

Gołembnik A., 2002, Wczesnośredniowieczny Płock, DiG, Warszawa.

Gołembnik A. (red.), 2011, Płock wczesnośredniowieczny, Trio, Warszawa.

Grabowski L., 1970, Katedra płocka, jej dzieje i zabytki, PWD, Płock. 
Grzybowski M., Zygner L., 2015, Episkopat Płocki w latach 1075-2015, TNP, Płock.

Górecki J., 1998, Kultowo-rezydencjonalny ośrodek pierwszych Piastów na Ostrowie Lednickim, Civitates Principales. Wybrane ośrodki władzy w Polsce wczesnośredniowiecznej, Katalog wystawy, Gniezno.

Kordala T., 1995, Płock w zaraniu dziejów, Wyd. Dom Kultury w Płocku, Płock.

Mroczko T., 1978, Polska sztuka przedromańska iromańska, Wyd. Artystycznei Filmowe, Warszawa.

Pianowski Z., 1994, "Sedes regni principales” Wawel i inne rezydencje piastowskie do połowy XIII wieku na tle europejskim, Seria: Architektura, Kraków.

Rodzińska-Chorąży T., 1995, Rozważania nad geneza rotund prostych w świetle nowych odkryć archeologicznych [w:] A.M. Wyrwa (red.), Studia i materiały do dziejów Pałuk, 2, s. 137-163.

Sikorski D.A., 2012, Wczesnopiastowska architektura sakralna, Wyd. Poznańskiego Towarzystwa Przyjaciół Nauk, Poznań.

Sokołowski Z., Sołtysiak M., 1975, Płock urbanistyka i architektura, Instytut Archeologii i Etnologii PAN, Warszawa.

Szafrański W., 1963, Archeologiczne badania wykopaliskowe na płockim Wzgórzu Tumskim w roku 1963, Notatki Płockie, 26, Płock.

Szafrański W., 1978, Początki i rozwój grodu i ośrodka miejskiego do roku 1138 [w:] A. Gieysztor (red.), Dzieje Płocka, Towarzystwo Naukowe Płockie, Płock.

Szafrański W., 1983, Płock we wczesnym średniowieczu, PAN, Zakład Narodowy im. Ossolińskich, Wrocław.

Świechowski Z., 2000, Poczatki Tysiąclecia, głos w konferencji, Warszawa.

Tomaszewski A., 1974, Romańskie kościoły z emporami zachodnimi na obszarze Polski, Czech i Wegier, PAN, Zakład Narodowy im. Ossolińskich, Wrocław.

Zachwatowicz J., 1971, Architektura [w:] M. Walicki (red.), Sztuka przedromańska i romańska do schyłku XIII wieku, 1, PWN, Warszawa.

Żurowska K. (red.), 1993, Ostrów lednicki: u progu chrześcijaństwa w Polsce, Gutenberg, Kraków. 


\section{The specific element in it's surrounding - remains. Roman Rotunda on Wzgórze Tumskie in Plock}

\section{ABSTRACT}

Since the dawn of the civilization the man - homo constructor - intuitively strives to create and recreate his surrounding in the manner known only to himself, in more or less durable ways. In this activity not only the magnificent constructions of men but also these of little posture become a reminiscence - sygnum - of human creativity of time past.

The article covers the history of roman rotunda - specific element in the cultural landscape of Wzgórze Tumskie in Plock, which remains not only as a trace of former architectural plan of this location, but is a real marker symbolically placed in a place of former existence.

It is a remain that not only stands in for obvious historical purpose but exposes the specific element in the landscape as well.

Key words: specific element, remain, rotunda

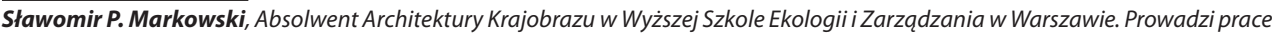
projektowe i prace realizacyjne z dziedziny projektowania ogrodów i parków zabytkowych. Autor artykułów i książek z dziedziny historii architektury i historii kultury.

Sławomir P. Markowski, Graduate in University of Ecology and Management in Warsaw. He conducts design and implementation works in the field of designing gardens and historic parks. Author of articles and books on the history of architecture and history of culture. 